\title{
PEMBERDAYAAN WANITA MELALUI PELATIHAN PEMBUATAN KIMCHI PADA IBU RUMAH TANGGA DI BATUJAJAR TIMUR BANDUNG BARAT
}

\author{
Perdina Nursidika ${ }^{1}$, Patricia Gita Naully ${ }^{2}$, dan Indria Astuti ${ }^{3}$ \\ ${ }^{1}$ Program Studi Teknologi Laboratorium Medis (D-4) Stikes Jenderal Achmad Yani Cimahi \\ ${ }^{2}$ Program Studi Kebidanan (S-1) Stikes Jenderal Achmad Yani Cimahi \\ E-mail: Perdina.sidika@gmail.com
}

\begin{abstract}
ABSTRAK. Masyarakat di desa Batujajar Timur memiliki masalah yang cukup kompleks, mulai dari bidang pendidikan, kesehatan, lingkungan hidup, sarana prasarana infrastruktur, ekonomi hingga sosial dan budaya. Namun, permasalahan yang menjadi prioritas adalah permasalahan di bidang ekonomi dan kesehatan. Di desa tersebut masih banyak masyarakat yang miskin dikarenakan kurangnya lapangan pekerjaan. Berdasarkan permasalahan yang telah dijabarkan, diberikan solusi yaitu melakukan pelatihan teknik fermentasi sayur sawi. Sayur sawi dipilih sebagai bahan makanan yang akan difermentasi karena merupakan salah satu komoditas pertanian yang cukup banyak dijumpai di desa Batujajar Timur. Tujuan pengabdian masyarakat ini adalah untuk meningkatkan keterampilan ibu rumah tangga dan meningkatkan perekonomian keluarga. Metode pelaksanaan pengabdian masyarakat ini diawali dengan pengurusan izin dan kerjasama dengan pihak desa Batujajar Timur, persiapan materi; persiapan alat bahan; pembuatan inoculum bakteri; dan fermentasi kimchi. Kegiatan utama yang dilakukan adalah pemberian pre test dan post test; pemberian materi; dan pelaksanaan praktik pembuatan kimchi. Hasil kegiatan pengabdian masyarakat ibu-ibu rumah tangga di Batujajar Timur memiliki kemampuan dan keterampilan dalam teknologi fermentasi kimchi.
\end{abstract}

Kata kunci: fermentasi; kimchi; pemberdayaan wanita

ABSTRACT. Communities in Batujajar Timur village have quite complex problems, ranging from education, health, the environment, infrastructure, economic to social and cultural infrastructure. However, the priority issues are economic and health issues. In the village there are still many poor people due to lack of employment. Based on the problems that have been outlined, a solution is given, which is training in mustard vegetable fermentation techniques. Vegetable mustard is chosen as a food ingredient that will be fermented because it is one of the agricultural commodities that is quite common in the Batujajar Timur Village. The aim of community service is to improve the skills of housewives and improve the family economy. This method of implementing community service begins with the management of permits and cooperation with the Batujajar Timur village, preparation of material; material preparation tools; preparation of bacterial inoculum; and kimchi fermentation. The main activities undertaken are the provision of pre-test and post-test; giving material; and the implementation of the practice of making kimchi. The results of community service activities of housewives in East Batujajar have the ability and skills in kimchi fermentation technology.

Key words: Fermentation; kimchi; women empowerment

\section{PENDAHULUAN}

Batujajar adalah sebuah kecamatan di Kabupaten Bandung Barat dengan luas wilayah sekitar $32 \mathrm{~km} 2$ yang terdiri dari tujuh desa, salah satunya yang akan dijadikan mitra yaitu desa Batujajar Timur. Desa Batujajar Timur terdiri dari 16 Rukun Warga (RW), 57 Rukun Tetangga (RT), dan 4,144 Kepala Keluarga (KK) (BPS, 2016). Penduduk Desa Batujajar Timur sejumlah 15.284 terdiri dari laki-laki sebanyak 7,717 jiwa dan perempuan sebanyak 7,567 jiwa dengan usia produktif yang paling banyak adalah 25-49 tahun (BPS, 2018).

Desa Batujajar Timur memiliki potensi yang luar biasa. Desa ini memiliki lahan 2,94 km2. Ada berbagai macam komoditas pertanian dan peternakan yang dapat dijumpai di desa ini. Komoditas pertanian yang cukup banyak dijumpai adalah palawija, jamur, tomat, cabai, jamur, dan sawi. Walaupun memiliki potensi alam yang baik, namun Desa Batujajar Timur masih memiliki masalah di bidang ekonomi dan kesehatan. Hingga saat ini, masih banyak penduduk desa tersebut yang tercatat sebagai masyarakat dengan tingkat ekonomi lemah. Kondisi ini dipengaruhi oleh beberapa faktor seperti keterbatasan lapangan kerja, meningkatnya jumlah pencari kerja yang berasal dari angkatan kerja baru dan pemutusan hubungan kerja (PHK), serta sedikitnya jumlah penduduk dengan pendidikan tinggi atau Sarjana (BPS, 2018).

Menurut data kepala Badan Ketahanan Pangan Daerah (BKPD) Jawa Barat tahun 2015, Kabupaten Bandung Barat memiliki desa miskin dengan jumlah terbanyak. Dari 165 desa/kelurahan sebanyak 42 diantaranya merupakan desa/kelurahan miskin tinggi (BPS, 2018). Sebanyak 19.200 KK merupakan keluarga miskin di Kabupaten Bandung Barat (Husodo, 2018). Sehingga perlunya peningkatan penguatan ekonomi dengan memanfaatkan sumber daya alam yang tersedia di Desa Batujajar Timur. Berlimpahnya hasil sayuran seperti sawi dengan daya jual yang rendah, bisa ditingkatkan dengan pelatihan mengubah sawi tersebut menjadi bernilai jual tinggi.

Pembuatan kimchi secara sederhana mudah dilakukan sehingga dapat mudah dilakukan di rumah sendiri. Kimchi merupakan hasil fermentasi yang dapat dimakan setiap hari. Kimchi merupakan makanan sehat karena efeknya terhadap kesehatan manusia (Cheigh \& Park, 1994)fermented Korean food that is prepared through a series of processes, including pretreatment of oriental cabbage (or radish. Pada saat difermentasi dengan berbagai 
sayuran dan bumbu, maka terdapat serat makanan, vitamin, bakteri asam laktat, mineral dan senyawa aktif yang ada dalam kimchi, seperti sawi, bawang putih, jahe, dan bubuk cabai (G.-R. Kim, Park, \& Lee, 2010). Kimchi memiliki kandungan aktif yang dapat mencegah penyakit jantung (H. J. Kim, Noh, \& Song, 2018).

Berdasarkan uraian pada analisis situasi Desa Batujajar Timur, maka berikut permasalahan mitra yang berhasil diidentifikasi, yaitu: 1. Masalah ekonomi: Desa Batujajar Timur masih termasuk desa miskin di Kabupaten Bandung Barat padahal memiliki potensi alam dan hasil bumi yang baik. Dengan adanya pelatihan ini, diharapkan peserta mampu memproduksi makanan sehat untuk keluarga sekaligus bisa meningkatkan perekonomian keluarga melalui penjualan produk hasil pelatihan yaitu kimchi.

Kegiatan ini merupakan Program Aksi pengembangan kemampuan masyarakat, yaitu melatih masyarakat dalam berbagai ketrampilan agar bisa menambah penghasilan dari ketrampilan tersebut. Pelatihan ini juga dimaksudkan untuk membuka wacana bagi Pemda setempat, dalam hal ini diwakili oleh Kecamatan Pamijahan, tentang metode peningkatan ketrampilan yang dapat dijadikan sebagai mata pencaharian baru bagi penduduk setempat.

\section{METODE}

Pelatihan teknik fermentasi sayur sawi bagi kelompok ibu rumah tangga di Desa Batujajar Timur, meliputi koordinasi dan pengurusan izin, persiapan alat dan bahan, pelatihan, dan pelaporan, dan publikasi di media cetak dan elektronik. Seluruh kegiatan pelatihan dilaksanakan bekerjasama dengan PKK Batujajar Timur. Tempat pelatihan di GOR Batujajar Timur Bandung Barat.

Kegiatan pelatihan diawali dengan pemberian pre test pengetahuan dasar mengenai kimchi dan pelatihannya. Tahap kedua adalah pemberian materi dalam bentuk pemberian teori dan video tutorial, materi yang diberikan seputar pengetahuan tentang teknik fermentasi yang tradisional dan modern. Kemudian, ibu-ibu diberikan pelatihan untuk membuat inokulum bakteri yang akan digunakan untuk fermentasi sayur sawi.

Proses pembuatan inokulum membutuhkan waktu 3 hari. Selanjutnya, ibu-ibu diberikan pelatihan untuk membuat kimchi dengan teknik fermentasi modern yang terstandardisasi dan cara menentukan waktu kadaluarsa. Selama pelatihan, kelompok ibu rumah tangga dilatih dan dibimbing oleh dosen yang ahli dibantu oleh mahasiswa yang sebelumnya sudah mendapatkan pelatihan berikut:

Adapun metode pelaksaan pelatihan sebagai

a. Persiapan Alat dan Bahan Alat

Alat dan bahan yang akan digunakan untuk pelatihan ini adalah labu Erlenmeyer, gelas kimia, batang pengaduk, mikropipet, kawat Oose, cawan Petri, bunsen, shaker, autoklaf, tips, timbangan, spatula, penangas, toples kaca, pisau, baskom, sarung tangan plastik, dan masker. Bahan yang akan digunakan pada kegiatan ini adalah kultur murni bakteri $L$. plantarum dan L. mesenteroides, medium Nutrient Broth (NB), Nutrient Agar (NA), Potato Dextrose Agar (PDA), $\mathrm{NaCl}$, glukosa, akuades, sawi putih, daun bawang, garam, bubuk cabai, saus tiram, jahe, dan bawang putih.

b. Pembuatan Bakteri Inokulum

Pembuatan inokulum bakteri Lactobacillus plantarum dan Leuconostoc mesenteroides diawali dengan proses aktivasi bakteri. Pada aktivasi pertama, sebanyak 3-5 Oose kultur bakteri diinokulasikan ke dalam $50 \mathrm{ml}$ medium NB yang telah ditambahkan glukosa $0,1 \%$. Kultur tersebut diinkubasi pada suhu ruang selama 24 jam dengan kecepatan agitasi $180 \mathrm{rpm}$. Selanjutnya proses aktivasi dilanjutkan pada tahap kedua. Kultur bakteri hasil aktivasi pertama diambil sebanyak 10\% dan diinokulasi ke dalam $50 \mathrm{ml}$ medium NB yang telah ditambahkan glukosa 0,1\%. Kultur tersebut diinkubasi kembali pada suhu ruang selama 24 jam dengan kecepatan agitasi $180 \mathrm{rpm}$. Kultur hasil aktivasi kedua diambil dan diinokulasi kembali pada medium NB yang telah ditambahkan glukosa $0,1 \%$. Jumlah bakteri yang diinokulasikan pada tahap tersebut harus mencapai $106 \mathrm{cfu} / \mathrm{ml}$. Proses inkubasi kultur dilakukan selama 9 jam untuk bakteri L. plantarum dan 4 jam untuk L. mesenteroides.

\section{c. Fermentasi Kimchi}

Sawi putih dicuci bersih dan dibelah menjadi dua. Sawi tersebut direndam dalam larutan garam 15\% (w/v) selama 3 jam. Setelah direndam, sayur sawi dibumbui dengan jahe yang telah dimemarkan, irisan daun bawang, bawang putih cincang, sedikit gula, serta bubuk cabai yang dilarutkan dalam saus tiram. Selanjutnya dilakukan penambahan inokulum L. mesenteroides dan L. plantarum 11 sebanyak $1 \%$ dengan perbandingan masing-masing bakteri sebesar 1:1. Campuran inokulum dan berbagai bumbu tersebut diaduk merata dan diletakkan dalam kendi tanah atau toples kaca yang ditutupi kain. Kendi atau toples disimpan pada suhu ruang $\left(20-25^{\circ} \mathrm{C}\right)$ selama 3 hari. d. Penentuan Waktu Kadaluarsa Kimchi yang telah matang kemudian diteruskan masa inkubasinya pada suhu ruang hingga suatu waktu yang menunjukkan jumlah sel mikroba pada kimchi telah mencapai 106 sel. Setiap 24 jam, air kimchi sebanyak $0,5 \mathrm{ml}$ diencerkan dengan 4,5 $\mathrm{ml}$ larutan fisiologis hingga suatu titik pengenceran tertentu. Kemudian 0,1 ml dari tiga titik pengenceran terakhir diinokulasikan ke cawan Petri berisi medium NA dan PDA. Kemudian, cawan agar yang telah diinokulasikan tersebut diinkubasi pada suhu ruang selama 24 jam lalu diamati dengan metode total plate count (TPC) 


\section{HASIL DAN PEMBAHASAN}

Pelaksanaan kegiatan ini diawali dengan pengurusan izin dan penentuan jadwal pengabdian masyarakat. Pengurusan izin meliputi izin kepada Puskesmas Batujajar dan Desa Batujajar Timur. Setelah izin dan penetuan jadwal, maka dilakukan sosialisasi pra pelatihan terhadap ibu ketua kader di 18 RW Batujajar Timur.

Kegiatan pengabdian masyarakat dilaksanakan di Gedung Olahraga (GOR) Batujajar Timur, dari mulai pukul 08.00 hingga 16.00, di aula desa Batujajar Timur. Pelatihan ini diikuti oleh 234 peserta, yang terdiri dari ibu-ibu rumah tangga yang merupakan kader PKK. Ibuibu peserta berasal dari 18 RW yang ada di Kecamatan Batujajar Timur.

Pelatihan diawali dengan pembagian kuesioner sederhana mengenai pengetahuan dasar ibu-ibu peserta mengenai kimchi dan manfaatnya. Pretest pengetahuan dasar ini berbentuk pernyataan sederhana dengan jawaban Ya/Tidak.

Jenis Pertanyaan tersebut adalah:

1. Apakah Anda mengetahui apa itu kimchi?

2. Apakah Anda mengetahui kimchi itu makanan sehat? 3. Apakah Pembuatan Kimchi mudah dilakukan?

4. Apakah menurut Anda pelatihan ini bermanfaat?

5. Apakah Anda akan memanfaatkan hasil penilaian Anda untuk meningkatkan pendapatan rumah tangga Anda?

6. Apakah Anda menginginkan pelatihan lain?

Hasil pretest menunjukkan sebagian besar peserta belum mengetahui apa itu kimchi dan manfaatnya secara kesehatan dan daya jualnya. Meskipun belum dilakukan pelatihan, hasil pretest menunjukkan bahwa pelatihan ini bermanfaat, namun peserta belum yakin bahwa hasil pelatihan bisa meningkatkan pendapatan rumah tangga. Semua peserta pun mengharapkan adanya pelatihan yang lain, yang dapat meningkatkan keterampilan dan pengetahuan ibu-ibu rumah tangga.

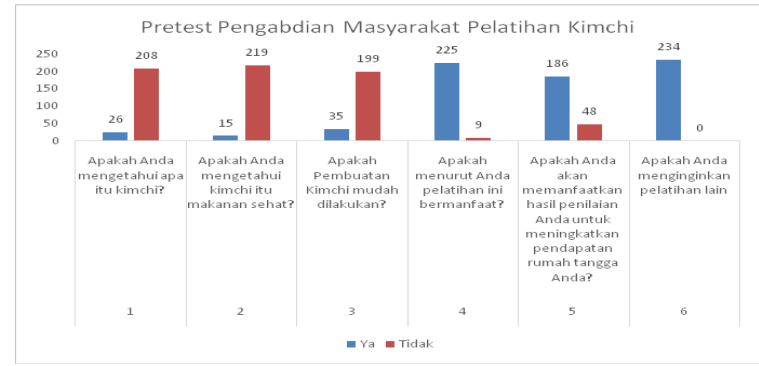

Gambar 1. Hasil pretest pelatihan kimchi

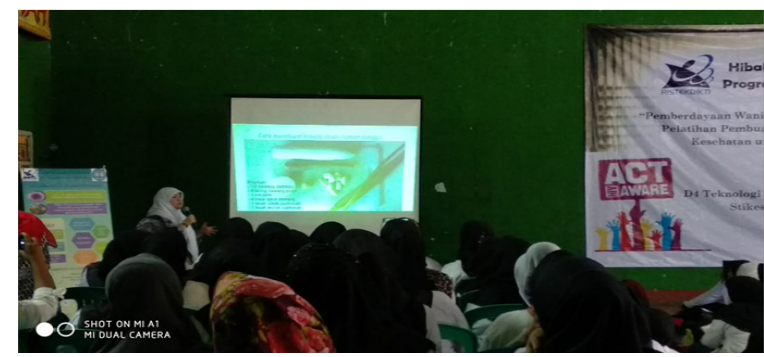

Gambar 2 Pemberian materi pelatihan pembuatan kimchi
Setelah pretest, maka dilaksanakan pemberian materi mengenai pelatihan kimchi dalam bentuk pemberian materi dan video tutorial.

Setelah pemberian materi, ibu-ibu langsung melaksanakan praktikum pelatihan pembuatan kimchi. Praktikum ini dilatih oleh dosen pelaksana, mahasiswa, dan laboran. Ibu-ibu melakukan persiapan dari mulai memotong sayuran, menyiapkan bumbu, memberikan bakteri fermenter, pengadukan, dan proses fermentasi. Sayur yang difermentasi kemudian difermentasi selama tiga hari untuk proses fermentasi.

Kimchi yang dibuat kemudian diuji di laboratorium untuk diperiksa masa kadaluarsanya. Uji lanjutan ini diperlukan karena dikhawatirkan ada bakteri pencemar pathogen yang bisa mengontaminasi produk kimchi. Bakteri pathogen dapat menyebabkan foodborne disease, yaitu penyakit yang disebabkan bakteri pathogen (Naully \& Mathilda, 2018). Bakteri pathogen bisa berefek sistemik dan mengganggu organ penting tubuh lain (Nursidika, Naully, \& Lestari, 2018). Uji kadaluarsa dilakukan dengan pengujian jumlah bakteri pada rentang waktu tertentu.

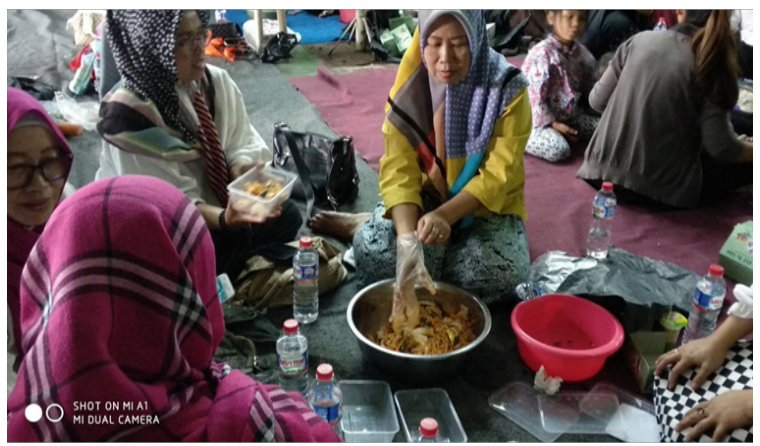

Gambar 3 Praktik pembuatan produk fermentasi kimchi

Setelah pelatihan, peserta diberikan post test dengan pertanyaan yang sama dengan pre test, dan didapat hasil pada gambar 4.

Setelah pemberian materi dan praktik membuat kimchi, peserta memahami $100 \%$ mengenai apa itu kimchi, pembuatan, manfaat kimchi untuk kesehatan dan perekonomian. Hasil post test menunjukkan semua peserta menginginkan pelatihan lain dan ingin menjadikan pelatihan ini sebagai salah satu upaya untuk peningkatan tingkat ekonomi keluarga.

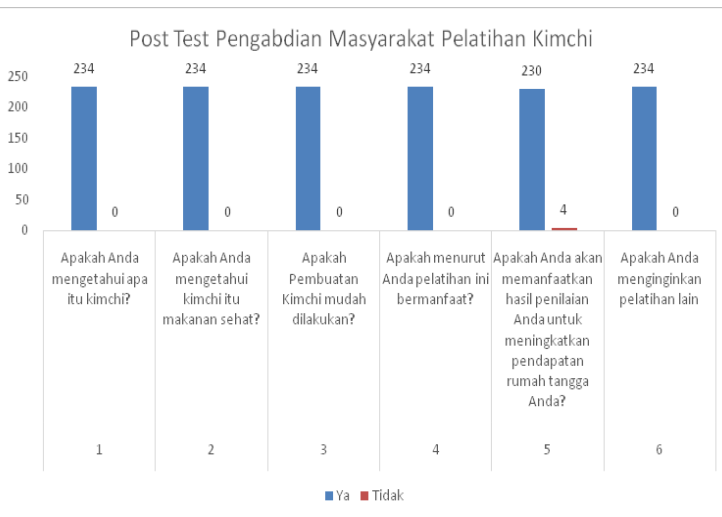

Gambar 4 Hasil post test pelatihan kimchi 
Hasil pelatihan ini menunjukkan bahwa ibu-ibu rumah tangga yang tergabung dalam PKK di desa Batujajar Timur sangat antusias dalam mengikuti pelatihan untuk meningkatkan keterampilan dan potensi diri, terutama bagi ibu-ibu yang menggantungkan pendapatan ekonomi keluarga hanya kepada suami (Wardiani, Intan, \& Subekti, 2018). Adanya pelatihan ini dapat meningkatkan perekonomian, karena dengan sawi mentah seharga Rp $7.000 / \mathrm{kg}$, bisa menjadi Rp 100.000/kg apabila sudah dibuat menjadi kimchi.

Pemberian edukasi dan keterampilan terhadap komunitas penting dilakukan, selain dapat meningkatkan kemampuan dasar juga dapat menghindari dari kejadian buruk dalam kehidupan (Naully \& Nursidika, 2019). Adanya pelatihan ini, membuat ibu rumah tangga dapat memiliki penghasilan sendiri, tanpa tergantung pada suami. Menurut Saptandari (1999), pemberdayaan terhadap wanita termasuk melibatatkan kaum perempuan tidak saja sebagai objek tetapi juga sebagai pelaku aktif, sebagai orang yang ikut merumuskan sendiri apa yang menjadi kebutuhan-kebutuhan mereka. Dengan penghasilan sendiri, maka ibu-ibu rumah tangga tersebut bisa membeli kebutuhan pribadi sesuai keputusannya.

Keberhasilan pemberdayaan ibu rumah tangga di Desa Batujajar Timur, dipengaruhi oleh kemauan, keaktifan, dan dukungan dari keluarga untuk melakukan pelatihan. Selain itu, PKK di Desa Batujajar Timur sangat aktif memfasilitasi kegiatan pengembangan anggotanya. Suksesnya pemberdayaan wanita didukung oleh berbagai faktor diantaranya peran organisasi komunitas local dalam hal ini PKK, tingkat partisipasi peserta, program pendampingan, dukungan, dan penghargaan (Pratama, 2013). Selain itu, keberhasilan pemberdayaan wanita dapat memanfaatkan hasil sumber daya alam local untuk berwirausaha (Astuti, 2017). Pelatihan ini memanfaatkan sumber alam local, yaitu sawi yang merupakan hasil pertanian yang banyak di Desa Batujajar Timur.

Selain itu, dengan adanya keterampilan pembuatan kimchi ibu rumah tangga dapat pula menghasilkan makanan sehat untuk keluarga (Hongu dkk., 2017). Makanan fermentasi seperti kimchi, dikenal sebagai makanan sehat dan memiliki fungsi bagi tubuh (Chang, 2018). Konsumsi kimchi secara rutin dapat mengurangi risiko kegemukan, meningkatkan imunitas tubuh, mencegah infeksi, dan mencegah penyakit degeneratif $(H$. J. Kim dkk., 2018).

\section{SIMPULAN}

Kegiatan pengabdian masyarakat ini diikuti oleh oleh 234 peserta, yang terdiri dari ibu-ibu rumah tangga yang merupakan kader PKK berasal dari 18 RW yang ada di Kecamatan Batujajar Timur. Kegiatan ini melakukan pelatihan pembuatan makanan fermentasi kimchi yang memanfaatkan sumber daya alam hasil pertanian khas daerah Batujajar Timur yaitu sawi. Dari kegiatan ini dapat disimpulkan bahwa pelatihan ini membawa manfaat untuk ibu rumah tangga dalam bidang kesehatan dan perekonomian. Ibu-ibu rumah tangga bisa memperoleh penghasilan sendiri, maka ibu-ibu rumah tangga tersebut bisa membeli kebutuhan pribadi sesuai keputusannya tanpa bergantung pada suami.

\section{UCAPAN TERIMAKASIH}

Ucapan terimakasih penulis ucapkan kepada Ristekdikti atas hibah Pengabdian Kepada Masyarakat Program Kemitraan Masyarakat pendanaan tahun 2019, seluruh civitas akademika Stikes Jenderal Achmad Yani Cimahi, Puskesmas Batujajar, PKK Desa Batujajar Timur, Program Studi Teknologi Laboratorium Medis (D-4), dan Program Studi Kebidanan (S-1).

\section{DAFTAR PUSTAKA}

Astuti, M. (2017). Pemberdayaan Perempuan Miskin Berbasis Pemanfaatan Sumberdaya Lokal Melalui Pendekatan Sosial Enterpreneurship (Studi Kasus di Daerah Tertinggal, Kabupaten Pasaman, Sumatera Barat). Sosio Konsepsia, 17(3), 241251. https://doi.org/10.33007/ska.v17i3.829

BPS. (2016). Kecamatan Cisarua Dalam Angka. Badan Pusat Statistik Kabupaten Bandung Barat. Bandung-Indonesia. Badan Pusat Statistik Kabupaten Bandung Barat.

BPS. (2018). Kecamatan Batujajar dalam Angka. Badan Pusat Statistik Kabupaten Bandung Barat.

Cheigh, H. S., \& Park, K. Y. (1994). Biochemical, microbiological, and nutritional aspects of kimchi (Korean fermented vegetable products). Critical Reviews in Food Science and Nutrition, 34(2), 175203. https://doi.org/10.1080/10408399409527656

Hongu, N., Kim, A. S., Suzuki, A., Wilson, H., Tsui, K. C., \& Park, S. (2017). Korean kimchi: Promoting healthy meals through cultural tradition. Journal of Ethnic Foods, 4(3), 172-180. https://doi. org/10.1016/j.jef.2017.08.005

Husodo,H. S. (2018,Agustus 30). 192.000 Warga Bandung Barat Masuk Kategori Miskin. PikiranRakyat. Diambil dari https://www.pikiran-rakyat.com/ bandung-raya/2018/08/30/192000-wargabandung-barat-masuk-kategori-miskin-429458

Kim, G.-R., Park, L.-Y., \& Lee, S.-H. (2010). Fermentation and Quality Characteristics of Kimchi Prepared Using Various Types of Maesil(Prumus mume Sieb. Et Zucc). Korean Journal of Food Preservation, 17(2), 214-222.

Kim, H. J., Noh, J. S., \& Song, Y. O. (2018). Beneficial Effects of Kimchi, a Korean Fermented Vegetable Food, on Pathophysiological Factors Related to Atherosclerosis. Journal of Medicinal Food, 21(2), 
127-135. https://doi.org/10.1089/jmf.2017.3946

Naully, P. G., \& Mathilda, F. (2018). Pencegahan Penyakit Akibat Jajanan Sekolah dengan Edukasi Kesehatan dan Undang-undang Perlindungan Konsumern. GEMASSIKA: Jurnal Pengabdian Kepada Masyarakat, 2(2), 80-90. https://doi. org/10.30787/gemassika.v2i2.277

Naully, P. G., \& Nursidika, P. (2019). Pendidikan Kesehatan: Upaya Mereduksi Angka Infeksi Menular Seksual pada Komunitas Homoseksual di Kota Bandung. CARADDE: Jurnal Pengabdian Kepada Masyarakat, 2(1), 53-59. https://doi. org/10.31960/caradde.v2i1.136

Nursidika, P., Naully, P. G., \& Lestari, L. A. (2018). Gambaran Bakteri Kontaminan pada Sikat
Gigi. The Journal Of Muhammadiyah Medical Laboratory Technologist, 2(1), 34-50-50. http:// dx.doi.org/10.30651/jmlt.v2i1.1804

Pratama, C. (2013). Faktor-faktor yang Mempengaruhi Keberhasilan Pemberdayaan Perempuan Desa Joho di Lereng Gunung Wilis. 1, 8.

Saptandari, P. (1999). Lima Tingkat Pemberdayaan Perempuan. Masyarakat Kebudayaan dan Politik, (2), 6 .

Wardiani, S. R., Intan, T., \& Subekti, M. (2018). Pemberdayaan Ibu Rumah Tangga dalam Upaya Peningkatan Ekonomi Keluarga di Desa Rancamulya dan Tambak Jati Kecamatan Patok Beusi-Subang. Dharmakarya, 7(4), 221-227. https://doi.org/10.24198/dharmakarya.v7i4.11922 